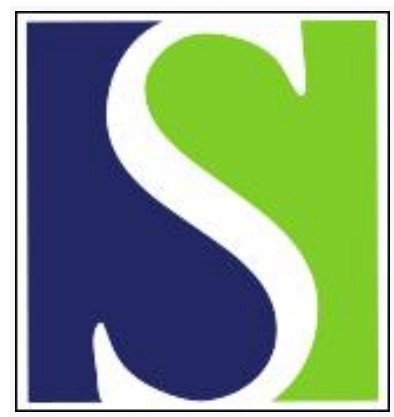

Scand J Work Environ Health 2013;39(1):46-56

https://doi.org/10.5271/sjweh.3314

Published online: 01 Aug 2012, Issue date: Jan 2013

Economic evaluation of a participatory return-to-work intervention for temporary agency and unemployed workers sick-listed due to musculoskeletal disorders

by Vermeulen SJ, Heymans MW, Anema JR, Schellart AJM, van Mechelen W, van der Beek AJ

The new participatory return-to-work program for temporary agency workers and unemployed workers, sick-listed due to MSD, was more costly than usual care, but enhanced work resumption and generated a net economic benefit for society due to productivity gain. Shared investments by government and employers are needed to enhance labor force participation of vulnerable working populations.

Affiliation: Department of Public and Occupational Health, EMGO Institute for Health and Care Research, P.O. Box 7057, 1007 MB, Amsterdam, The Netherlands. h.anema@vumc.nl

Refers to the following text of the Journal: 2010;36(4):273-288

The following articles refer to this text: 2015;41(5):421-424;

2018;44(5):458-474

Key terms: costâ $€$ "benefit analysis; costâ $€$ "effectiveness analysis; economic evaluation; evaluation; intervention; labor force participation; MSD; musculoskeletal disorder; return-to-work; social insurer perspective; societal perspective; sustainable return-to-work; temporary agency worker; unemployed worker; vulnerable worker population; worker without employment contract

This article in PubMed: www.ncbi.nlm.nih.gov/pubmed/22854773

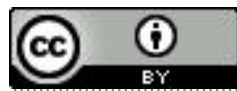




\title{
Economic evaluation of a participatory return-to-work intervention for temporary agency and unemployed workers sick-listed due to musculoskeletal disorders
}

\author{
by Sylvia J Vermeulen, MD, 1, 2 Martijn W Heymans, PhD, ,, 4 Johannes R Anema, PhD, ${ }^{1,2}$ Antonius JM \\ Schellart, PhD, 1, 2 Willem van Mechelen, PhD, ${ }^{1,2}$ Allard J van der Beek, PhD 1,2
}

\begin{abstract}
Vermeulen SJ, Heymans MW, Anema JR, Schellart AJM, van Mechelen W, van der Beek AJ. Economic evaluation of a participatory return-to-work intervention for temporary agency and unemployed workers sick-listed due to musculoskeletal disorders. Scand J Work Environ Health. 2013;39(1):46-56. doi:10.5271/sjweh.3314
\end{abstract}

\begin{abstract}
Objective The aim of the study was to evaluate the cost-effectiveness, -utility, and -benefit of a newly developed participatory return-to-work (RTW) program for temporary agency and unemployed workers, sick-listed due to musculoskeletal disorders.

Methods An economic evaluation was conducted alongside a randomized controlled trial with a 12-month follow-up. Temporary agency and unemployed workers, sick-listed for 2-8 weeks due to musculoskeletal disorders, were randomized to the participatory RTW program $(\mathrm{N}=79)$ or usual care group $(\mathrm{N}=84)$. The new RTW program was aimed at making a consensus-based RTW action plan with the possibility of a temporary (therapeutic) workplace. Effect outcomes were sustainable RTW and quality-adjusted life years (QALY). Healthcare utilization was measured from the social insurer's perspective and societal perspective.
\end{abstract}

Results Total healthcare costs in the participatory RTW program group [10 189 (standard deviation [SD] 7055) euros] were statistically significantly higher compared to care-as-usual [7862 (SD 7394) euros]. The cost-effectiveness analyses showed that the new intervention was more effective but also more costly than usual care (ie, to gain RTW one day earlier in the participatory RTW program group, approximately 80 euros needed to be invested). The net societal benefit of the participatory RTW program compared to care-as-usual was 2073 euros per worker.

Conclusions The newly developed participatory RTW program was more effective but also more costly than usual care. The program enhanced work resumption and generated a net socioeconomic benefit. Hence, implementation of the participatory RTW program may have potential to achieve a sustainable contribution of vulnerable workers to the labor force.

Key terms cost-effectiveness analysis; cost-benefit analysis; labor force participation; social insurer perspective; societal perspective; sustainable return-to-work; vulnerable worker population; worker without employment contract.

The socioeconomic impact of musculoskeletal disorders (MSD) among the working population is significant. Findings in the international literature consistently have shown that MSD-related long-term sickness absence, ie, chronic work disability, accounts for the majority of these societal costs (1-5). Direct healthcare costs represent only a minor part of the economic burden.

To achieve evidence-based and efficient occupa- tional healthcare it is essential to gain insight into the relationship between the input of financial resources and the achieved results. From this perspective, there is a forthcoming demand for methodological high quality economic evaluation of occupational healthcare interventions $(6,7)$. The key question is whether the beneficial effect(s) of a (newly developed) intervention is worth the (extra) costs, when compared to, for instance,

1 Department of Public \& Occupational Health, EMGO Institute for Health \& Care Research, VU University Medical Centre, Amsterdam, The Netherlands.

2 Research Centre for Insurance Medicine AMC-UMCG-UWV-VUmc, City, The Netherlands.

3 Department of Health Sciences, EMGO Institute for Health \& Care Research, Faculty of Earth \& Life Sciences, VU University, Amsterdam, The Netherlands.

4 Department of Epidemiology and Biostatistics, VU University Medical Centre, Amsterdam, The Netherlands.

Correspondence to: Johannes R Anema, MD, PhD, Department of Public and Occupational Health, EMGO Institute for Health and Care Research, P.O. Box 7057, 1007 MB, Amsterdam, The Netherlands. [E-mail: h.anema@vumc.nl] 
usual care. After all, provided the presence of substantial effects, an intervention with higher costs can still be cost-effective. Conversely, a low-cost intervention is not necessarily the most cost-effective.

Within the field of occupational healthcare research, development of return-to-work (RTW) interventions for sick-listed workers with non-standard labor agreements (eg, temporary agency and unemployed workers) is uncommon (8). In contrast, the number of non-standard workers is rapidly growing. To illustrate: in 1998 the private employment agency industry constituted of approximately 4.8 million agency workers [fulltime equivalent (FTE)] worldwide (9). Ten years later, in 2008, this number had nearly doubled to 9.5 million agency workers (FTE) across the globe (9). In addition, in the Netherlands in 2008, nearly 3300 private employment agencies provided 242000 fulltime jobs (daily average number of FTE). These workers with non-standard labor agreements, however, represent a vulnerable group within the working population as they are characterized by a poorer health status, a greater distance to the labor market, and an increased risk for (long-term) work disability (10). In the Netherlands, application for a disability benefit is three times higher for these workers compared to employees (11), accounting for $40 \%$ of the long-term disability claims received by the Dutch Institute for Employee Benefit Schemes (12). To put this into perspective, the total annual costs for work disability benefits in the Netherlands in 2007-2008 were approximately 17 billion euros (13) and nearly 20 billion euros in 2009 (14).

Therefore, a participatory RTW program was developed for temporary agency and unemployed workers, sick-listed due to MSD (8). The newly developed participatory RTW program consists of a stepwise process to identify and solve obstacles for RTW, resulting in a consensus-based RTW plan to facilitate work resumption. An important goal of this program is to let the sick-listed worker (re)gain control over his/her RTW process. Moreover, the program is guided by an independent RTW coordinator. To warrant equality and active participation in the new RTW program, both the sicklisted worker and the labor expert from the Dutch Social Security Agency, who guides the worker with regard to vocational rehabilitation, should be involved. To offer the possibility of work resumption in a temporary (therapeutic) workplace, agreements were made with commercially operating vocational rehabilitation agencies to find suitable (therapeutic) workplaces matching with the formulated RTW plan.

The objective of this study was to conduct an economic evaluation of the participatory RTW program compared to usual care. Cost-effectiveness was evaluated from both the social insurers' and societal perspective. Cost-benefit and -utility were evaluated from the societal perspective.

\section{Methods}

\section{Study design}

An economic evaluation from a social insurers' and societal perspective was conducted alongside a randomized controlled trial. The study was carried out in collaboration with five front offices of the Dutch Social Security Agency (a government funded agency that provides supportive income and occupational healthcare for this study population) and four large Dutch vocational rehabilitation agencies. The Medical Ethics Committee of the VU University Medical Center approved the study design, protocol, and procedures. All participants gave written informed consent. A detailed description of the study design has been presented elsewhere (15). The study is listed in the Netherlands Trial Register (NTR) under NTR1047.

\section{Study population}

The study was performed between March 2007 and September 2009. Eligible participants were temporary agency workers and unemployed workers (18-64 years), sick-listed for 2-8 weeks with MSD as the main health complaint of their sickness benefit claim. An overview of the inclusion and exclusion criteria has been presented elsewhere (15).

\section{Randomization and blinding}

Randomization was performed at worker level. Workers were pre-stratified by type of worker (temporary agency or unemployed worker) and type of last job (degree of physical/mental demands). Further details regarding the randomization procedure and blinding have been described elsewhere $(15,16)$.

\section{Interventions}

Usual care group. In the Netherlands, sick-listed workers who have either no employment or no longer an employment contract (ie, no employer/workplace to return to) receive sickness benefit and occupational healthcare by the Social Security Agency for the duration of (established) work disability. The occupational healthcare is provided by an insurance physician, a labor expert, and a case manager. The content of occupational healthcare has been reported more thoroughly elsewhere (16).

Participatory RTW program group. The intervention group also received usual care. In addition, they were referred by their insurance physician to an independent RTW coordinator for the new participatory RTW program. The detailed content of the new participatory RTW program has previously been presented elsewhere $(15,16)$. The 
primary aim of the participatory RTW program was to enhance early (sustainable) work resumption as a step toward durable contribution to the labor force.

\section{Effects}

The primary measure of effect was duration until sustainable RTW, defined as the duration in calendar days from the day of randomization until RTW in paid regular work or regular work with supportive sickness benefit for $\geq 28$ consecutive calendar days. The secondary outcome was quality-adjusted life years (QALY). Healthrelated quality of life was measured using the EuroQol5D (17). The utility (on a scale of 0-1) of the reported health states was estimated using the Dutch tariff (18). QALY were calculated as utility multiplied by time spent in a particular health state. Transitions between health states were linearly interpolated (19).

\section{The Dutch social security context}

As a semi-government institution, the Dutch Social Security Agency performs statutory duties that are funded with public money, ie, (financial) responsibility to provide supportive income and vocational rehabilitation support for work-disabled workers without an employment contract. However, although the Social Security Agency is an institute under the control of the government, it enjoys a certain degree of independence. With regard to spending of public vocational rehabilitation funds, the Social Security Agency is an important decision-maker. Similarly, an employer is an important decision-maker regarding payment of occupational healthcare-related costs for work-disabled employees, such as payment of wages and provision of vocational rehabilitation support. Hence, in line with recent economical evaluations for participatory RTW interventions for regular employees $(20,21)$, an economical evaluation was conducted from the social insurer's and societal perspective. From the social insurer's perspective, costs for occupational healthcare and paid sickness benefit were included. From the societal perspective, in addition to the Social Security Agency costs, direct healthcare and direct non-healthcare costs were included.

\section{Costs resources and valuation}

Healthcare costs. Data were collected using questionnaires at 3-, 6-, 9-, and 12-months follow-up, measuring resource use with a 3 -month recall period. The questionnaires included direct healthcare and non-healthcare costs. Direct healthcare costs included primary and secondary care visits, home care, and medication use. Direct non-healthcare costs included alternative medical care, informal help, and daycare costs. Prices used for valuing resource utilization are presented in table 1. Dutch standard cost prices were used (22). Medication costs were valued with cost prices of the Royal Dutch Society for Pharmacy (23). Data on occupational healthcare by the Social Security Agency were collected from the continuous database registration and the medical files at the Social Security Agency. The costs were calculated based on real cost prices. The (real) costs for applied occupational healthcare interventions, including costs for placement in therapeutic workplaces in the intervention group, were extracted from the database records. Costs of the participatory RTW program (excluding costs of placement in therapeutic workplaces) were calculated using a bottom-up approach (see table 2). The index year for this study was 2008 .

Sickness benefit costs. The costs of sickness benefits for the participants who did not return to paid work during follow-up were retrieved from the Social Security Agency database records. The total amount of paid sickness benefits was collected for each participant after the 12-month follow-up. These data consisted of real costs.

Productivity. In case of sick leave of regular employees, productivity loss is calculated. However, productivity loss during sick leave was not measured in this study. When reporting sick, a temporary agency or unemployed worker immediately falls under the Social Security Agency for supportive income, ie, sickness benefit. Furthermore, as soon as possible, the sick-listed worker is replaced with a healthy temporary agency worker. With regard to the sick-listed unemployed workers, these workers were already out of work when reporting sick and thus no productivity loss is present. Hence, the paid sickness benefit costs were calculated in this study.

Productivity gain during follow-up was also measured. In case of work resumption in a temporary workplace, the Social Security Agency paid sickness benefit and the employer profited from the productivity of the worker. Productivity gain was, therefore, defined as the economic benefit (from a societal perspective) of the productivity of a worker during work resumption with ongoing sickness benefit. In addition, we assumed that in case of work resumption in regular work with ending of the sickness benefit, there was no net productivity gain from a societal perspective. This is comparable to other recent economic evaluations of participatory RTW interventions for regular employees $(20,21)$, ie, in case of work resumption of regular employees (and subsequent ending of sick leave) production loss ends and no net productivity gain is assumed.

We also assumed that workers were $100 \%$ productive during the hours of work resumption in a temporary workplace. To calculate the productivity gain during work resumption with ongoing sickness benefit, the 
Table 1. Healthcare resource use, cost prices used, and means and standard deviations (SD) of healthcare utilization per group (based on the crude, non-imputed, cost data). [RTW=return to work]

\begin{tabular}{|c|c|c|c|c|c|c|c|c|}
\hline \multirow[t]{2}{*}{ Type of healthcare } & \multicolumn{2}{|c|}{$\begin{array}{l}\text { Price per unit } \\
\text { (euros) }\end{array}$} & \multicolumn{3}{|c|}{$\begin{array}{c}\text { Participatory RTW program } \\
\text { (euros) }\end{array}$} & \multicolumn{3}{|c|}{$\begin{array}{l}\text { Usual care } \\
\text { (euros) }\end{array}$} \\
\hline & Cost & Range & Mean costs & $\%$ & SD & Mean costs & $\%$ & SD \\
\hline \multicolumn{9}{|l|}{ Occupational healthcare } \\
\hline Insurance physician & $53^{a}$ & & 108.8 & & 81.8 & 70.9 & & 62.4 \\
\hline Labour expert & $41^{\mathrm{a}}$ & & 32.1 & & 43.6 & 14.0 & & 28.9 \\
\hline Case manager & $29^{a}$ & & 16.7 & & 21.2 & 35.5 & & 33.9 \\
\hline Missing value range & & & \multicolumn{3}{|c|}{0} & \multicolumn{3}{|c|}{0} \\
\hline \multicolumn{9}{|l|}{ Primary care } \\
\hline General practitioner & $22^{\mathrm{b}}$ & & 31.0 & & 85.9 & 23.7 & & 46.1 \\
\hline Physical therapist & $25^{b}$ & & 261.5 & & 478.8 & 253.8 & & 434.8 \\
\hline Caesar therapist ${ }^{\mathrm{c}}$ & $25^{b}$ & & 12.9 & & 114.7 & 25.2 & & 122.9 \\
\hline Manual therapist & $34^{b}$ & & 70.6 & & 389.1 & 87.0 & & 392.3 \\
\hline Alternative therapist ${ }^{\mathrm{d}}$ & & $10-78$ a,b & 40.1 & & 146.3 & 16.5 & & 84.7 \\
\hline Other care practitioners ${ }^{\mathrm{e}}$ & & $8-500$ a,b & 140.1 & & 546.9 & 36.5 & & 104.7 \\
\hline \multicolumn{9}{|l|}{ Outpatient care } \\
\hline Medical specialist & $74^{b}$ & & 175.9 & & 465.4 & 126.9 & & 269.4 \\
\hline X-ray photo & $45^{b}$ & & 26.5 & & 46.5 & 39.8 & & 83.5 \\
\hline MRI scan & $179^{b}$ & & 54.4 & & 119.4 & 53.3 & & 117.2 \\
\hline CT scan & $147^{\mathrm{b}}$ & & 13.0 & & 53.4 & 12.2 & & 46.7 \\
\hline Lumbar puncture & $47^{b}$ & & 0.6 & & 5.3 & 7.2 & & 43.9 \\
\hline Blood tests & $23^{b}$ & & 10.5 & & 27.2 & 12.4 & & 26.5 \\
\hline Other diagnostic tests ${ }^{f}$ & & $36-1308$ a,b & 7.1 & & 23.6 & 21.2 & & 143.0 \\
\hline Hospitalization & $439^{b}$ & & 61.2 & & 279.0 & 88.9 & & 346.2 \\
\hline Medication use & & $0.1-271^{g}$ & 169.3 & & 523.1 & 227.7 & & 1103.1 \\
\hline Informal care costs & & $6-29$ b & 848.0 & & 1610.1 & 795.4 & & 1810.5 \\
\hline Missing value range & & & \multicolumn{3}{|c|}{$19.0-22.8$} & \multicolumn{3}{|c|}{$14.3-21.4$} \\
\hline
\end{tabular}

a Price according to professional organization or health care provider.

b Price according to Dutch guidelines for costing studies.

${ }^{c}$ Aimed at prevention and treatment of complaints resulting from improper posture or movement pattern

${ }^{\mathrm{d}}$ Consisting of 14 different alternative therapists.

${ }^{\mathrm{e}}$ Consisting of 17 different care practitioners.

${ }^{\dagger}$ Consisting of 13 different diagnostic tests.

${ }^{g}$ Price according to the Royal Dutch Society for Pharmacy.

total number of working hours (with ongoing sickness benefit) during the 12-month follow-up was multiplied by the estimated price of productivity per hour based on age and gender $(20,21)$. Level of education was not part of the proxy for estimation of productivity gain because, at baseline, the level of education was higher in the intervention group. This would have resulted in higher productivity estimates in favor of the intervention group.

\section{Data analysis}

The economic evaluation was performed according to the intention-to-treat principle. Discounting of costs was not applied because the follow-up was one year (24). Data on RTW and paid benefits were collected for all participants from the Social Security Agency database. With regard to the self-reported resource use (consisting of direct healthcare and direct non-healthcare utilization), a complete follow-up was available for 116 participants $(71.2 \%)$.

Missing cost data were completed by means of the multivariate imputation by chained equations (MICE) procedure (25). To prevent that extreme high cost values were used to substitute missing values during the impu- tation process, an alternative MICE procedure was used (26). This method consisted of the following steps: (i) for each cost variable, cost values at the $90^{\text {th }}$ percentile and higher were replaced by the total group mean separately; (ii) an imputation model was composed containing complete cost information assessed at all follow-up times in combination with important baseline demographic and prognostic variables such as gender, type of work, and functional disability; (iii) this imputation model was used to create ten multiple imputed datasets; and (iv) before the data entered the main analysis, the original cost data that were replaced by the mean cost value in the first step were set back to the original value in all ten datasets. These steps were done separately in the intervention and control group data and afterwards datasets were merged. To pool effects and costs from these ten complete, Rubin's rules were used (27).

For the cost-effectiveness analysis (CEA), incremental cost-effectiveness ratios (ICER) were calculated by dividing the incremental costs by the incremental effects. The ICER represents the additional costs needed to gain one extra unit of effect in the intervention group compared to the usual care group. For the cost- 
Table 2. Overview of costs of the participatory return-to-work (RTW) program. [SSA=Social Security Agency]

\begin{tabular}{|c|c|c|}
\hline Resources & Description & $\begin{array}{l}\text { Aggregated costs } \\
\quad \text { (euros) }\end{array}$ \\
\hline \multicolumn{3}{|l|}{$\begin{array}{l}\text { Costs for training insurance physicians, } \\
\text { labor experts and RTW coordinators }\end{array}$} \\
\hline Trainer costs & $\begin{array}{l}\text { Training sessions; } 3 \text { trainers, } 12-16 \text { hours, } 70-106 \text { euros per hour. Preparation } \\
\text { training: } 2 \text { trainers, } 2-8 \text { hours, } 106 \text { euros per hour. }\end{array}$ & 4226 \\
\hline $\begin{array}{l}\text { Attendance costs insurance physicians, } \\
\text { labor experts, and RTW coordinators }\end{array}$ & $\begin{array}{l}\text { Primary and follow-up training of insurance physicians and labor experts: } 5-7 \text { insur- } \\
\text { ance physicians, } 6-8 \text { labor experts, } 7 \text { hours, } 81-106 \text { euros per hour. Primary and } \\
\text { follow-up training of RTW coordinators: 6-9 RTW coordinators, } 10 \text { hours, } 81 \text { euros } \\
\text { per hour. }\end{array}$ & 14635 \\
\hline Additional training costs & Rent for training location, refreshments, and study materials. & 1118 \\
\hline Total training costs & Sum of trainer costs, attendance costs, and additional costs. & 19979 \\
\hline Training costs per worker & $\begin{array}{l}\text { Assumption: minimum of } 20 \text { workers at each SSA front office can receive the RTW } \\
\text { program. }\end{array}$ & 200 \\
\hline \multicolumn{3}{|l|}{$\begin{array}{l}\text { Costs for carrying out the participatory } \\
\text { RTW program }\end{array}$} \\
\hline $\begin{array}{l}\text { Costs of time investment insurance } \\
\text { physician }\end{array}$ & $\begin{array}{l}\text { Mean extra time investment of the insurance physician for referral of } 38 \text { workers to } \\
\text { the RTW coordinator, } 0.25 \text { hour per worker, } 106 \text { euros per hour. }\end{array}$ & 1005 \\
\hline Costs of time investment labor expert & $\begin{array}{l}\text { Mean extra time investment of the labor expert was } 2.4 \text { hours per worker, } 81 \text { euros per } \\
\text { hour, } 38 \text { workers had the meetings with the labor expert and the RTW coordinator. }\end{array}$ & 7287 \\
\hline Costs of time investment RTW coordinator & $\begin{array}{l}\text { Mean time investment of the RTW coordinator was } 3.9 \text { hours per worker, } 81 \text { euros } \\
\text { per hour, } 38 \text { workers. }\end{array}$ & 12043 \\
\hline $\begin{array}{l}\text { Professional costs per worker referred to the } \\
\text { RTW coordinator }\end{array}$ & & 535 \\
\hline \multicolumn{3}{|l|}{ Total costs per worker } \\
\hline $\begin{array}{l}\text { Total costs per worker not referred to the } \\
\text { RTW coordinator }\end{array}$ & Constitutes of the training costs per worker. & 200 \\
\hline $\begin{array}{l}\text { Total costs per worker referred to the RTW } \\
\text { coordinator }\end{array}$ & $\begin{array}{l}\text { Sum of training costs per worker and costs of time investment of the insurance } \\
\text { physician, the labor expert, and the RTW coordinator }(200+535) \text {. }\end{array}$ & 735 \\
\hline
\end{tabular}

utility analyses (CUA), the incremental cost-utility ratio (ICUR) was calculated by the difference in total costs (all healthcare and sickness benefit costs) divided by the difference in QALY. The cost-benefit analysis (CBA) was conducted from a societal perspective and calculated the net monetary benefit by subtracting the difference in total costs between the intervention and usual care groups from the difference in productivity gain between the two groups. Additionally, a return on investment, in which the monetary benefit is expressed as a percentage of the cost of the investment was calculated by dividing the incremental benefit (gain minus cost) by the incremental costs of the investment (20).

Uncertainty surrounding the incremental costs was estimated using non-parametric bootstrapping with 5000 replications (28). The $95 \%$ confidence intervals $(95 \%$ $\mathrm{CI})$ around the mean cost differences were estimated using the approximate bootstrap confidence (ABC) algorithm (29). Bootstrapped cost-effect pairs were plotted on a cost-effectiveness plane, and a cost-effectiveness acceptability curve was estimated if the ICER was located in the north-east quadrant (30).

A sensitivity analysis for the CBA was conducted to assess the effect of reduced productivity during placement in a temporary workplace with ongoing sickness benefit. We repeated the CBA assuming 75\% productivity during therapeutic work resumption. Data processing was performed in SPSS 17.0 (SPSS Institute, Cary,
NC, USA). Calculation of 95\% CI and CEA and CUA analyses were conducted in R version 2.12 (31). For all analyses, a P-value of 0.05 (two-tailed) was considered statistically significant.

\section{Results}

\section{Participants}

Based on the returned screening questionnaires, 784 potentially eligible workers were identified. Of those, 163 workers were enrolled in the study, signed informed consent, and were randomized to the participatory RTW program $(\mathrm{N}=79)$ or the usual care $(\mathrm{N}=84)$ groups. The recruitment flow and baseline characteristics have been reported in detail elsewhere (16). Statistically significant differences in baseline characteristics between participants with and without complete follow-up were more present among younger persons $(\mathrm{P}=0.002)$, men $(\mathrm{P}=0.02)$, temporary agency workers $(\mathrm{P}=0.01)$, and participants who had worked until the first day of reporting sick $(\mathrm{P}=0.001)$ in the group without a complete follow-up.

\section{Effects on RTW and QALY}

The median duration until sustainable first RTW was 161 
[interquartile range (IQR) 88-365] days in the participatory RTW program group and 299 (IQR 71-365) days in the usual care group $(\mathrm{P}=0.10)$. The mean QALY (on a scale of $0-1$ ) in the participatory RTW program group was 0.63 [standard deviation (SD) 0.22] and 0.58 (SD $0.26)$ in the usual care group $(\mathrm{P}=0.35)$.

\section{Healthcare utilization}

There were some non-significant differences in the use of (non-occupational) healthcare between both groups (see table 1). With respect to the received occupational healthcare, participants in the participatory RTW program group had significantly more consultations with the insurance physician $(\mathrm{P}=0.001)$ and the labor expert $(\mathrm{P}=0.002)$, whereas controls had significantly more meetings with the case-manager at the Social Security Agency $(\mathrm{P}=0.000)$.

\section{Costs}

The total costs of the participatory RTW program were 735 euros per worker (table 2). These costs consisted of (i) the mean costs of training per worker (200 euros), including trainer costs, training attendance costs for the occupational healthcare professionals, and additional training costs; and (ii) the mean occupational healthcare professional costs per worker (535 euros), representing the costs for the additional time investment by the insurance physician, the labor expert, and the RTW coordinator. Table 3 shows the total healthcare costs in both groups during the 12-month follow-up. The costs for occupational healthcare and the total Social Security Agency costs were statistically significantly higher in the participatory RTW program group. Direct healthcare and non-healthcare costs did not statistically differ between the two groups. Total healthcare costs were statistically significantly higher in the intervention group, mostly due to the higher Social Security Agency costs.

\section{Cost-effectiveness analysis}

The CEA from the social insurer's perspective showed an ICER of -76 for sustainable RTW, meaning that an additional 76 euros was needed in the participatory RTW program group for RTW one day earlier, compared to care as usual. The cost-effectiveness plane (figure 1a) shows that $89 \%$ of the bootstrap cost-effect pairs were located in the north-east quadrant, indicating that the participatory RTW program was more effective and associated with higher costs than usual care. The costeffectiveness acceptability curve (figure $1 \mathrm{~b}$ ) showed a 0.80 probability of the participatory RTW program being cost-effective compared to usual care if one is willing to pay 200 Euros for RTW one day earlier.

The CEA from a societal perspective differed slightly
Table 3. Total mean effects and costs and differences in mean total effects and costs during 12-month follow-up (where applicable pooled effects and costs are presented). [SD=standard deviation; $95 \% \mathrm{Cl}=95 \%$ confidence interval; $\mathrm{QALY}=$ qualityadjusted life years; $\mathrm{OHC}=0$ ccupational healthcare; $\mathrm{SSA}=$ Socia Security Agency; RTW=return to work].

\begin{tabular}{|c|c|c|c|c|c|c|}
\hline & \multicolumn{2}{|c|}{$\begin{array}{c}\text { Participatory } \\
\text { RTW program } \\
(\mathrm{N}=79)\end{array}$} & \multicolumn{2}{|c|}{$\begin{array}{l}\text { Usual care } \\
\qquad(N=84)\end{array}$} & \multirow[b]{2}{*}{$\begin{array}{l}\text { Mean } \\
\text { differ- } \\
\text { ence }\end{array}$} & \multirow[b]{2}{*}{$95 \% \mathrm{Cl}$} \\
\hline & $\begin{array}{l}\text { Mean } \\
\text { total }\end{array}$ & SD & $\begin{array}{l}\text { Mean } \\
\text { total }\end{array}$ & SD & & \\
\hline & \multicolumn{6}{|c|}{ Effects } \\
\hline $\begin{array}{l}\text { Days until sustain- } \\
\text { able RTW }\end{array}$ & 199 & 128 & 227 & 145 & -28 & $-71-14$ \\
\hline QALY (pooled) & 0.63 & 0.22 & 0.58 & 0.26 & $0.05-$ & $-0.04-0.13$ \\
\hline \multicolumn{7}{|l|}{ Costs } \\
\hline $\mathrm{OHC}$ by the $\mathrm{SSA}^{\mathrm{a}}$ & 1904 & 1856 & 930 & 1512 & 975 & $448-1500$ \\
\hline Paid sickness benefit & 6151 & 5943 & 4995 & 6265 & $1156-$ & $-735-3046$ \\
\hline Total SSA costs ${ }^{b}$ & 8056 & 6413 & 5925 & 6486 & 2131 & $216-4211$ \\
\hline $\begin{array}{l}\text { Total primary care } \\
\text { costs (pooled) }\end{array}$ & 610 & 884 & 480 & 696 & 130 & $-108-384$ \\
\hline $\begin{array}{l}\text { Total outpatient care } \\
\text { costs (pooled) }\end{array}$ & 382 & 645 & 384 & 751 & -2 & $-235-196$ \\
\hline $\begin{array}{l}\text { Informal care costs } \\
\text { (pooled) }\end{array}$ & 954 & 1598 & 834 & 1802 & 120 & $-429-614$ \\
\hline $\begin{array}{l}\text { Medication costs } \\
\text { (pooled) }\end{array}$ & 186 & 521 & 238 & 1102 & -52 & $-484-125$ \\
\hline $\begin{array}{l}\text { Total healthcare costs } \\
\text { (pooled) }{ }^{c}\end{array}$ & 10189 & 7055 & 7862 & 7394 & 2327 & $51-4465$ \\
\hline \multicolumn{7}{|c|}{$\begin{array}{l}\text { a Calculated by adding participatory RTW program costs, OHC profes- } \\
\text { sional costs, and applied OHC interventions costs (this included the } \\
\text { costs for placement in a temporary workplace in the intervention } \\
\text { group). } \\
\text { b Calculated by adding sickness benefit costs and OHC costs. }\end{array}$} \\
\hline
\end{tabular}

with an ICER of -82 , meaning that an additional 82 euros needs to be invested in the participatory RTW program to achieve RTW one day earlier, compared to care as usual. Additionally, the cost-effectiveness plane (figure 2a) showed that $88 \%$ of the bootstrap cost-effect pairs were located in the north-east quadrant. The costeffectiveness acceptability curve (figure $2 b$ ) showed a 0.75 probability of the participatory RTW program being cost-effective compared to usual care if one is willing to pay 200 euros for RTW one day earlier.

\section{Cost-utility analysis}

There was a small non-significant difference in QALY gained over 12 months $(0.05$ on a scale of $0-1)$ in favor of the participatory RTW program group (table 3), and the cost difference was 2327 euros resulting in a large positive ICUR of $46540(2327 / 0.05)$. This means that 46 540 euros needs to be invested in the participatory RTW program to gain one QALY per worker. Furthermore, the majority of the pooled cost-QALY pairs (ie, $85 \%$ ) were located in the north-east quadrant of the cost-utility plane (not shown) indicating that the new intervention was more effective and more costly compared to care-as-usual. 

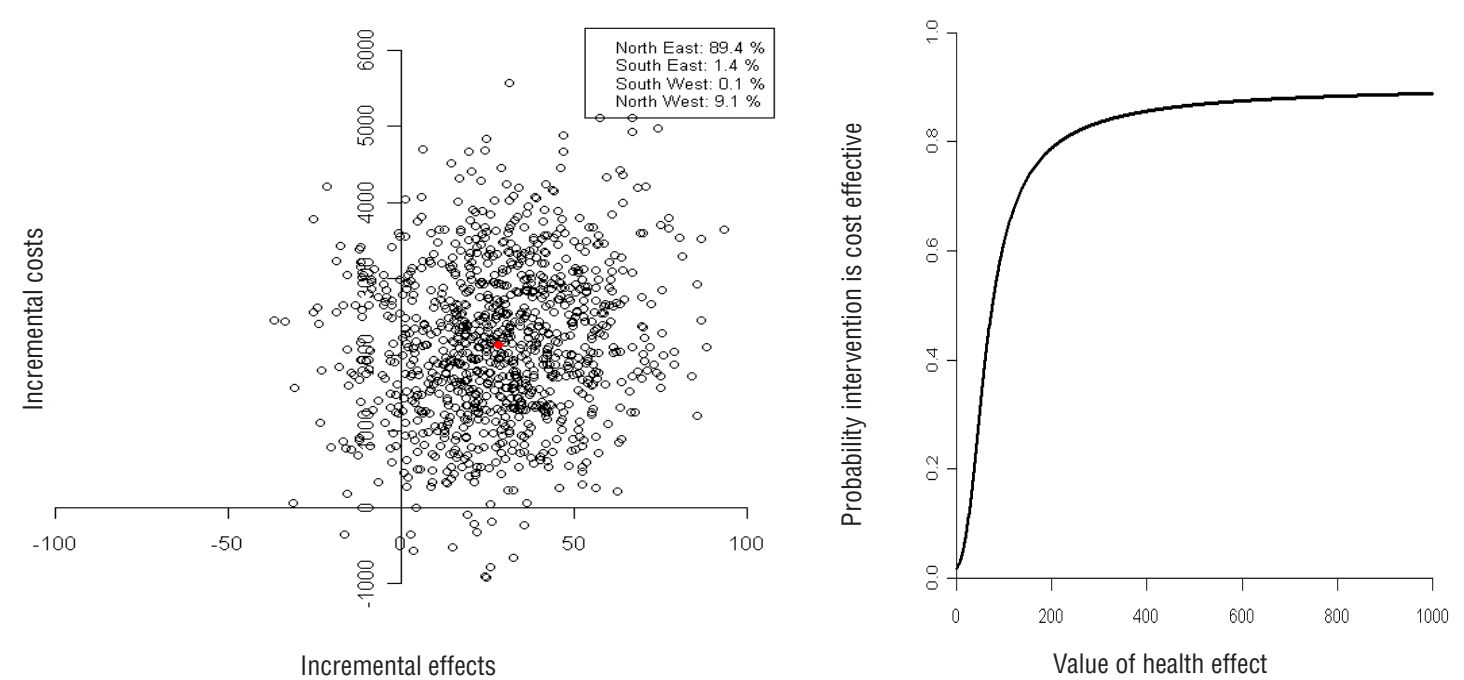

Figures 1a and 1b. Cost-effectiveness plane and acceptability curves for the difference in return to work (RTW) after 12 months from social insurer's perspective.

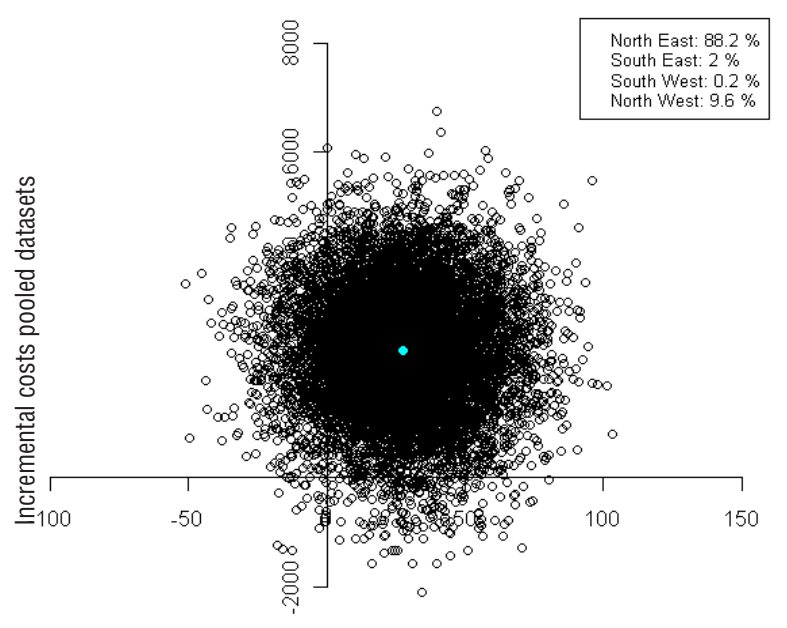

Incremental effects pooled datasets

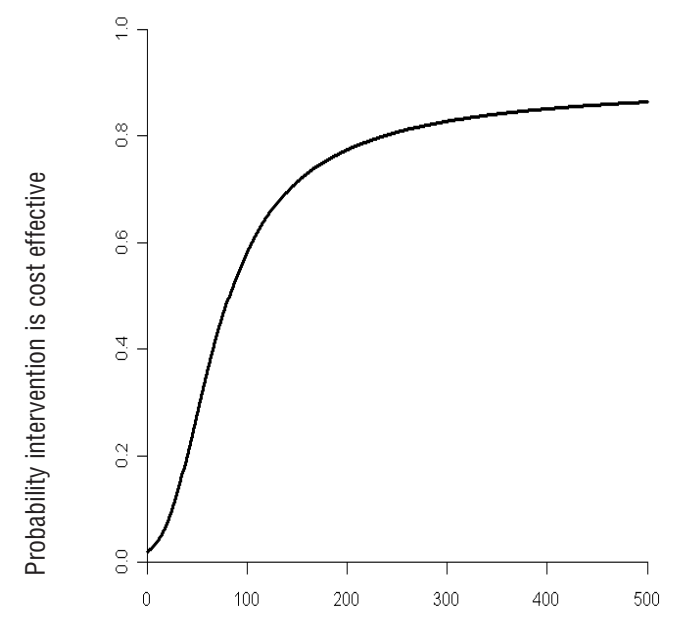

Value of health effect

Figure $\mathbf{2 b}$. Cost-effectiveness plane and acceptability curves for the difference in return to work (RTW) after 12 months from societal perspective.

\section{Cost-benefit analysis}

The CBA from a societal perspective showed that the mean difference in total healthcare costs was 2327 euros (95\% CI 42-4465 euros) in favor of the usual care group. The benefit (difference in productivity yield) was 4400 euros (95\% CI 1969-7499 euros) per worker in favor of the participatory RTW program. The return on investment from a societal perspective was $89 \%$ [(4400 - 2327/2327 euros) $\times 100$ ]; ie, every euro invested in the new intervention yielded 0.89 euro profit. The net societal benefit of the participatory RTW program compared to care-as-usual was 2073 euros (4400 - 2327 euros) per worker.

The results of the sensitivity CBA (assuming 75\% productivity during work resumption with supportive sickness benefit) showed a monetary benefit of 3300 euros (95\% CI 1607-5736 euros) in favor of the participatory RTW program group and a net societal benefit, compared to care-as-usual, of 973 euros $(3300-2327$ euros) per worker.

\section{Discussion}

\section{Main findings}

The participatory RTW program was more effective but also more costly than usual care. The total Social Security Agency costs (occupational healthcare and sickness 
benefit) and the total societal costs (all healthcare and sickness benefit) were statistically significantly higher in the participatory RTW program group. This was mainly due to higher costs associated with the new intervention. However, from a societal perspective, the new intervention resulted in a net economic benefit of 2073 euros per worker compared to care-as-usual.

\section{Strengths of this study}

In this study, several strengths can be identified. First, this study had a pragmatic randomized controlled trial design, ie, the study was conducted in a real-life Dutch occupational healthcare practice. Second, both the social insurer's and the societal perspective were used for the economic evaluation. The existence of the Dutch Social Security Agency is closely linked with Dutch Society and its Social Security system. However, as a semi-government institution, it enjoys certain independence. As such, the Social Security Agency is an important decision-maker as to the use of public money for provision of sickness benefit and vocational rehabilitation support for sick workers without an employment contract. Therefore, in our opinion, monetizing the program costs from both perspectives provided the most comprehensive economic evaluation. A third strength of the study was the use of the Social Security Agency database for the collection of RTW data and sickness benefit data, and subsequently the cross-checking of these data with other sources, namely: (i) the client files at the Social Security Agency, (ii) the reports in the newly developed computerized support system, and (iii) the selfreport questionnaires. Furthermore, because the amount of awarded sickness benefit depends on the former salary of a sick-listed worker, we checked if the use of actual sickness benefit costs did not lead to unwanted variation in both groups. The mean sickness benefit costs per worker day during the 12-month follow-up were comparable for both groups (usual care: 31.07 euros per day; participatory RTW program: 31.42 euros per day).

The final strength of this study was the collection of the occupational healthcare costs. Two recent costeffectiveness studies on participatory RTW interventions in the Netherlands did not register costs for work adaptations resulting from the consensus-based RTW plan $(20,21)$. This may have resulted in an underestimation of RTW program costs. In our study, we not only collected the costs for usual care in both groups, but also registered the additional costs (based on real prices) for sociomedical guidance and applied interventions as part of the new participatory RTW program.

\section{Limitations of this study}

Several methodological limitations should be acknowledged. First, the use of retrospective questionnaires may have biased the data. A possible alternative could have been prospective data collection using cost diaries. However, we believe that the influence of recall bias may be limited since findings in the literature show that recall information for 3 months is valid (32). Second, net cumulative working hours were used as a proxy for productivity. Reduced productivity following RTW, ie, socalled presenteeism (33), was not measured in this study. However, evidence suggests that productivity may be decreased ranging from $5-16 \%$ as a result of production loss due to health problems $(34,35)$. Nonetheless, we believe that overestimation of productivity in our study was limited. Offering the possibility of a gradual RTW with a stepwise increase in working hours (and a subsequent increase in productivity) was part of the new RTW program. Furthermore, to take into account the possibility of a reduced productivity after RTW, we performed a sensitivity analysis assuming $75 \%$ productivity after work was resumed. In our opinion, in view of the aforementioned literature findings, this might be a conservative approach. A third limitation of the study is related to the relatively high degree of loss to follow-up for the self-reported questionnaires. Long-term follow-up is essential to evaluate the outcome of a newly developed intervention critically. However, it is known that loss of participants to follow-up can affect the final conclusions of an outcome study (36). The results can be considered more robust because we incorporated the $29 \%$ of participants with partial cost data in the analysis. To limit the presence of biased estimates of the self-reported healthcare utilization, we used the MICE methodology (18). The MICE methodology assumes a normal distribution for each variable $(26,37)$. Simulation studies showed that in general MICE performs well in non-normally distributed data (37). Handling non-normally distributed continuous data, which is characteristic of cost data, can, however, require an alternative MICE procedure (26). In our dataset, we noticed that the highest cost values, which could be attributed to some workers who were sick-listed for a long time (cost drivers), were also used to impute the missing values. To prevent overestimation of group mean values, we applied an alternative MICE procedure. Before the imputations started we replaced the cost values that were at the $90^{\text {th }}$ percentile or higher, by their group mean. The strength of this procedure is that the imputation model is more or less corrected for patients with extreme high values, ie, missing values are estimated by using data from all "normal" workers and not determined by workers who are responsible for the highest costs. This generated more plausible and representative cost data in our trial. A fourth limitation was the use of first instead of full RTW as an outcome measure. Because the workers in our study had no "own work" to which they could return, work resumption in any type of paid work or RTW to work with ongoing 
benefits for $\geq 28$ consecutive (calendar) days was considered first sustainable RTW. However, full RTW (ie, work resumption in previous or equal work) as a measure of successful removal of all RTW limitations could have increased the impact of our study findings. In addition, the use of full RTW as the primary outcome measure could have made it easier to compare our results with similar studies that investigated participatory RTW interventions for other worker groups $(20,21)$.

Finally, caution is needed when generalizing the results of this study to another context, eg, to other countries. The participatory RTW program was specifically tailored for our study population and the Dutch context in which it was implemented. When using the participatory RTW program in a different setting, the population characteristics and the (social, political and cultural) context in which the program will be implemented and used need to be taken into account.

\section{Comparison with other studies}

The importance of applying RTW interventions closely linked to a workplace has been emphasized by several authors $(38,39)$. In addition, RTW interventions focusing on consensus-based work-related adaptations, eg, a change in working hours or work design, with active involvement of important stakeholders can reduce work disability duration and associated costs $(39,40)$. However, to our knowledge, cost-effectiveness studies investigating comparable RTW interventions on work-related outcomes for workers without (relative) permanent employment relationships are, to date, not available. Up to now, there have been only a few economic evaluations of participatory RTW interventions aimed at sicklisted regular employees $(20,32,41,42)$. These studies showed that a participatory RTW intervention was costeffective and -beneficial among sick-listed employees with (acute or chronic) low-back pain $(20,41,42)$. For employees with stress-related mental disorders, no overall cost-effectiveness was found (21), but for the subgroup of employees with baseline intentions to RTW despite their symptoms, the workplace intervention was significantly more effective and less costly.

In this study, the costs of the workplace intervention itself (training and additional time-investment by the occupational healthcare professionals) were in line with earlier developed participatory RTW interventions for sick-listed employees in the Netherlands $(20,21)$. However, although the aforementioned studies also showed that, compared to care-as-usual, additional (direct) costs are needed to perform a participatory RTW intervention, application of the intervention among sick-listed employees with low-back pain resulted in earlier RTW against substantial lower total healthcare costs, ie, a substantial lower ICER was reported, in comparison with our study findings. A possible explanation for this is the fact that, in contrast to regular employees, in our study the sick-listed workers had no workplace to which he/ she could return. To find suitable temporary workplaces, vocational rehabilitation agencies were contracted and offered a financial reward for their services. In addition, as incentive for employers, the worker was placed in a temporary workplace with ongoing supportive benefit from the Social Security Agency. Hence, additional costs were needed to realize earlier RTW.

\section{Study implications}

Economic evaluations carried out alongside pragmatic randomized trials are increasingly common in occupational healthcare research because it is important to assess costs and cost-effectiveness apart from work-related and health-related outcomes. Moreover, the results of these economic evaluations are essential to convince policymakers that implementation of a new RTW intervention is a worthwhile and necessary investment. In this study sustainable RTW was enhanced by making a consensusbased RTW action plan (with a key role for the independent RTW coordinator) and by offering the possibility of a suitable temporary workplace. From a societal perspective, the RTW program increased social participation of vulnerable workers, and generated a net economic benefit due to productivity gain. Hence, from a general perspective, implementation of the participatory RTW program may potentially enhance a productive contribution of vulnerable workers to the labor force. However, investments were on the part of the Social Security Agency (and thus from public money) and benefits were on the part of the employers. This division in costs and benefits will, very likely, make implementation more challenging. From this perspective, several possibilities should be taken into account. Firstly, it is important to emphasize the importance of using community money to enhance social participation of vulnerable working populations in order to increase their contribution to the labor market. In addition, given the international trend of an ageing workforce, there is a need for active labor market policies (43) in order to utilize and strengthen present and potential labor force sources. Moreover, within the framework of an active labor market policy, it may be possible to extend already existing Dutch arrangements for subsidized (temporary) workplaces for young disabled workers to other groups of vulnerable workers, eg, sick-listed unemployed workers. By realizing subsidized (temporary) workplaces, costs and benefits can be shared between the Social Security Agency and the employers. Secondly, a potential solution could be to increase the responsibilities of employers with regard to facilitation of RTW of sick-listed workers without an employment contract. From this perspective, it can be recommended to assess the possibilities to make 
temporary agencies more responsible for RTW of sicklisted temporary agency workers, ie, offering a suitable workplace for (therapeutic) RTW and having financial responsibilities with regard to vocational rehabilitation costs. Finally, creating a network of potential (temporary) workplaces and not having to contract commercially operating vocational rehabilitation agencies could reduce the costs for applying the new RTW program.

\section{Concluding remarks}

The newly developed participatory RTW program for temporary agency and unemployed workers, sick-listed due to MSD, was more effective but also more costly compared to care-as-usual. To gain RTW one day earlier by using the participatory RTW program, approximately 80 euros needed to be invested. However, from a societal perspective, there was a net monetary benefit after 12 months. Every euro invested yielded a net profit of 0.89 euro due to productivity gains. In our opinion, implementation of the new RTW program might be a worthwhile investment to enhance a sustainable and productive contribution of vulnerable workers to the labor force.

\section{Acknowledgements}

We would like to thank the data management department of the Dutch Social Security Agency for supplying the cost data. We also thank Karlijn van Beurden and Karin Groenewoud for their help with data entry. This study was financially supported by the Dutch Institute for Employee Benefit schemes.

The author declare that they have no competing interests.

\section{References}

1. Lambeek LC, van Tulder MW, Swinkels IC, Koppes LL, Anema JR, van Mechelen W. The trend in total cost of back pain in The Netherlands in the period 20022007. Spine. 2010;36:1050-8. http://dx.doi.org/10.1097/ BRS.0b013e3181e70488.

2. Hashemi L, Webster BS, Clancy EA, Volinn E. Length of disability and cost of workers'compensation low back pain claims. J Occup Environ Med. 1997;39:937-45. http://dx.doi. org/10.1097/00043764-199710000-00005.

3. Hashemi L, Webster BS, Clancy EA, Courtney TK. Length of disability and cost of work-related musculoskeletal disorders of the upper extremity. J Occup Environ Med. 1998;40:26169. http://dx.doi.org/10.1097/00043764-199803000-00008.

4. Maniadakis N, Gray A. The economic burden of back pain in the UK. Pain. 2000;84:95-103. http://dx.doi.org/10.1016/ S0304-3959(99)00187-6.

5. Pai S, Sundaram LJ. Low back pain: an economic assessment in the United States. Orthop Clin North Am. 2004;35:1-5. http://dx.doi.org/10.1016/S0030-5898(03)00101-9.

6. Tompa E, Dolinschi R, de Oliveira C, Irvin E. A systematic review of occupational and safety interventions with economic analyses. J Occup Environ Med. 2009;51:1004-23. http:// dx.doi.org/10.1097/JOM.0b013e3181b34f60.

7. Uegaki K, de Bruijne MC, Lambeek L, Anema JR, van der Beek AJ, van Mechelen W, van Tulder MW. Economic evaluations of occupational health care interventions from a company's perspective: a systematic review of methodological quality. Scand J Work Environ Health. 2010;36:273-88. http:// dx.doi.org/10.5271/sjweh.3017.

8. Vermeulen SJ, Anema JR, Schellart AJM, van Mechelen W, van der Beek AJ. Intervention mapping for development of a participatory return-to-work intervention for temporary agency workers and unemployed workers sick-listed due to musculoskeletal disorders. BMC Public Health. 2009;9:216. http://dx.doi.org/10.1186/1471-2458-9-216.

9. Confédération Internationale des Entreprises de Travail Temporaire (CIETT). The agency work industry around the world. Economic Report 2010 Edition. Brussels: International Confederation of Private Employment Agencies CIETT; 2010.

10. Vermeulen SJ, Tamminga SJ, Schellart AJM, Ybema JF, Anema JR. Return-to-work interventions for sick-listed workers without an employment contract - what works? BMC Public Health. 2009;9:232. http://dx.doi.org/10.1186/14712458-9-232.

11. de Jong P, Veerman T, van der Burg C, Schrijvershof C. Nederland is niet ziek meer. Van WAO-debakel naar WIAmirakel. Onderzoek in opdracht van Stichting Instituut GAK [The Netherlands is not sick any more. From WAO-debacle to WIA-miracle. Research commissioned by Stichting Instituut GAK]. Amsterdam/Leiden: APE/Astri; 2010.

12. UWV [Dutch Institute for Employee Benefit Schemes]. Kwartaal verkenning 2009-I [Quarterly survey 2009-I]. Kenniscentrum UWV, directie SBK. Amsterdam, April 2009.

13. Uitvoeringsinstituut Werknemersverzekeringen. UWV jaarverslag 2008 [Dutch Institute for Employee Benefit Schemes annual report 2008]. Amsterdam: UWV.

14. Uitvoeringsinstituut Werknemersverzekeringen. UWV jaarverslag 2009 [Dutch Institute for Employee Benefit Schemes annual report 2009]. Amsterdam: UWV.

15. Vermeulen SJ, Anema JR, Schellart AJM, van Mechelen W, van der Beek AJ. Cost-effectiveness of a participatory return-to-work intervention for temporary agency workers and unemployed workers sick-listed due to musculoskeletal disorders: design of a randomized controlled trial. BMC Musculoskelet Disord. 2010;11:60. http://dx.doi. org/10.1186/1471-2474-11-60.

16. Vermeulen SJ, Anema JR, Schellart AJM, Knol DL, van Mechelen W, van der Beek AJ. A participatory return-to-work intervention for temporary agency workers and unemployed workers sick-listed due to musculoskeletal disorders: results of 
a randomized controlled trial. J Occup Rehabil. 2011;21:31324. http://dx.doi.org/10.1007/s10926-011-9291-7.

17. Brooks R. EuroQol.: the current state of play. Health Policy. 1996;37:53-72. http://dx.doi.org/10.1016/01688510(96)00822-6.

18. Lamers LM, Stalmeijer PF, McDonnell J, Krabbe PF, van Busschbach JJ. Kwaliteit van leven in economische evaluaties: het Nederlands EQ-5D tarief [Measuring the quality of life in economic evaluations: the Dutch EQ-5D tariff]. Ned Tijdschr Geneesk. 2005;149:1574-78.

19. Dolan P. Modeling valuations for EuroQol health states. Medical Care. 1997;35:1095-1108. http://dx.doi. org/10.1097/00005650-199711000-00002.

20. Lambeek LC, Bosmans JE, Van Royen BJ, van Tulder MW, van Mechelen W, Anema JR. Effect of integrated care for sick-listed patients with chronic low back pain: economic evaluation alongside a randomised controlled trial. BMJ. 2010;341:c6414. http://dx.doi.org/10.1136/bmj.c6414.

21. van Oostrom SH, Heymans MW, de Vet HC, van Tulder MW, van Mechelen W, Anema JR. Economic evaluation of a workplace intervention for sick-listed employees with distress. Occup Environ Med. 2010;67:603-10. http://dx.doi. org/10.1136/oem.2009.051979.

22. Oostenbrink JB, Koopmanschap MA, Rutten FF. Handleiding voor kostenonderzoek, methoden en standaard kostprijzen voor economische evaluaties [Manual for cost studies, methods, and standard cost-prices for economic evaluations in healthcare]. Rotterdam: Board of health care insurance; 2004.

23. Z-index. G-standard. The Hague: The Netherlands; 2006.

24. van der Roer N, Boos N, van Tulder MW. Economic evaluations: a new avenue of outcome assessment in spinal disorders. Eur Spine J. 2006;15 (Suppl 1):S109-S117. http:// dx.doi.org/10.1007/s00586-005-1052-x.

25. Van Buuren $\mathrm{S}$, Oudshoorn CG. Multivariate Imputation by Chained Equations. Leiden, The Netherlands: TNO; 2000.

26. White IR, Royston P, Wood AM. Multiple imputation using chained equations: Issues and guidance for practice. Stat Med. 2011;30:377-99. http://dx.doi.org/10.1002/sim.4067.

27. Rubin DB. Multiple imputation for nonresponse in surveys. New York: John Wiley \& Sons; 1987. http://dx.doi. org/10.1002/9780470316696.

28. Briggs AH, Wonderling DE, Mooney CZ. Pulling costeffectiveness analysis up by its bootstraps: a non-parametric approach to confidence interval estimation. Health Econ .1997;6:327-40. http://dx.doi.org/10.1002/(SICI)10991050(199707)6:4<327::AID-HEC282>3.0.CO;2-W.

29. Efron B, Tibshirani RJ. An introduction to the bootstrap. New York: Chapman \& Hall; 1993.

30. Briggs A, Fenn P. Confidence intervals or surfaces? Uncertainty on the cost-effectiveness plane. Health Econ. 1998;7:723-40. http://dx.doi.org/10.1002/(SICI)10991050(199812)7:8<723::AID-HEC392>3.0.CO;2-O.

31. R Development Core Team. R: A language and environment for statistical computing. Vienna, Austria; R Foundation for Statistical Computing; 2011.
32. van den Brink M, van der Hout WB, Stiggelbout AM, Putter H, van de Velde CJ, Kievit J. Self-reports of health-care utilization: diary or questionnaire? Int J Technol Assess Healh Care. 2005;21:298-304. http://dx.doi.org/10.1017/ S0266462305050397.

33. Schultz AB, Edington DW. Employee health and presenteeism: a systematic review. J Occup Rehabil. 2007;17:547-79. http:// dx.doi.org/10.1007/s10926-007-9096-x.

34. Brouwer WB, van Exel NJ, Koopmanschap MA, Rutten FF. Productivity costs before and after absence from work: as important as common? Health Policy. 2002;61:173-87. http:// dx.doi.org/10.1016/S0168-8510(01)00233-0.

35. Berger ML, Howell R, Nicholson S, Sharda C. Investing in healthy human capital. J Occup Environ Med. 2003;45:121325. http://dx.doi.org/10.1097/01.jom.0000102503.33729.88.

36. Murray DW, Britton AR, Bulstrode CJK. Loss to follow-up matters. J Bone Joint Surg Br. 1997;79:254-7. http://dx.doi. org/10.1302/0301-620X.79B2.6975.

37. van Buuren S. Multiple imputation of discrete and continuous data by fully conditional specification. Stat Methods Med Res. 2007;16:219-42. http://dx.doi. org/10.1177/0962280206074463.

38. Krause N, Dasinger LK, Neuhauser F. Modified work and return to work: a review of the literature. J Occup Rehabil. 1998;8:11339. http://dx.doi.org/10.1023/A:1023015622987.

39. Franche RL, Cullen K, Clarke J, Irvin E, Sinclair S, Frank $\mathrm{J}$, et al. Workplace-based return-to-work interventions: a systematic review of the quantitative literature. J Occup Rehabil. 2005;15:607-31. http://dx.doi.org/10.1007/s10926005-8038-8.

40. van Oostrom SH, Driessen MT, de Vet HC, Franche RL, Schonstein E, Loisel P, et al. Workplace interventions for preventing work disability. Cochrane Database Syst Rev 2009;15:CD006955.

41. Loisel P, Lemaire J, Poitras S, Durand MJ, Champagne F, Stock S, et al. Cost-benefit and cost-effectiveness analysis of a disability prevention model for back pain management: a six year follow up study. Occup Environ Med. 2002;59:807-15. http://dx.doi.org/10.1136/oem.59.12.807.

42. Steenstra IA, Anema JR, van Tulder MW, Bongers PM, de Vet $\mathrm{HC}$, van Mechelen W. Economic evaluation of a multi-stage return to work program for workers on sick-leave due to low back pain. J Occup Rehabil. 2006;16:557-78. http://dx.doi. org/10.1007/s10926-006-9053-0.

43. Cooke M. Policy changes and the labor force participation of older workers: evidence from six countries. Can J Aging. 2006;25:387-400. http://dx.doi.org/10.1353/cja.2007.0015.

Received for publication: 2 February 2012 